\title{
Measuring the Effects of Pre-College Engineering, Year 3
}

\section{Dr. Noah Salzman, Boise State University}

Noah Salzman is an Assistant Professor at Boise State University, where he is a member of the Electrical and Computer Engineering Department and IDoTeach, a pre-service STEM teacher preparation program. His work focuses on the transition from pre-college to university engineering programs, how exposure to engineering prior to matriculation affects the experiences of engineering students, and engineering in the K-12 classroom. He has worked as a high school science, mathematics, and engineering and technology teacher, as well as several years of electrical and mechanical engineering design experience as a practicing engineer. He received his Bachelor of Science degree in Engineering from Swarthmore College, his Master's of Education degree from the University of Massachusetts, and a Master's of Science in Mechanical Engineering and Doctorate in Engineering Education from Purdue University.

\section{Dr. Matthew W. Ohland, Purdue University, West Lafayette}

Matthew W. Ohland is Professor of Engineering Education at Purdue University. He has degrees from Swarthmore College, Rensselaer Polytechnic Institute, and the University of Florida. His research on the longitudinal study of engineering students, team assignment, peer evaluation, and active and collaborative teaching methods has been supported by the National Science Foundation and the Sloan Foundation and his team received Best Paper awards from the Journal of Engineering Education in 2008 and 2011 and from the IEEE Transactions on Education in 2011. Dr. Ohland is Chair of the IEEE Curriculum and Pedagogy Committee and an ABET Program Evaluator for ASEE. He was the 2002-2006 President of Tau Beta Pi and is a Fellow of the ASEE and IEEE.

\section{Dr. Monica E Cardella, Purdue University, West Lafayette}

Monica E. Cardella is the Director of the INSPIRE Institute for Pre-College Engineering Education and is an Associate Professor of Engineering Education at Purdue University. 


\title{
Measuring the Effects of Pre-College Engineering, Year 3
}

\begin{abstract}
With the increased national focus on STEM education, many states now including engineering as part of their education standards for both students and teachers, and the popularity of cocurricular and extracurricular engineering activities, young people have unprecedented ability to explore engineering prior to matriculation in a university engineering program. This study uses a mixed-methods exploratory approach to examine how exposure to pre-college engineering programs affects the experiences of university engineering students. Conducting and analyzing phenomenographic interviews with cohorts of first year engineering students yielded five qualitatively different ways undergraduate engineering students experience the transition from pre-college to university engineering: Foreclosure, Frustration, Tedium, Connection, and Engaging Others.
\end{abstract}

Utilizing the results of these interviews, we developed a quantitative instrument to explore the relationship between pre-college engineering participation and students' transitions into firstyear engineering programs at a larger scale. Results of the administration of a pilot version showed high overall reliability for the instrument as a whole, as well as high reliability for sets of items associated with the different ways of experiencing the transition from pre-college to university engineering.

The results of this research will help engineering administrators, instructors and designers of undergraduate and pre-college curricula adapt to students' changing needs and abilities as a result of their increased experience with engineering prior to university.

\section{Background}

With the recent national focus on improving and increasing access to STEM education, many K12 students now have the opportunity to study and experience engineering in many different contexts prior to matriculation in a university engineering program. With the growing inclusion of engineering content in many states education standards ${ }^{1,2}$ and the inclusion of significant engineering learning outcomes in the Next Generation Science Standards ${ }^{3}$, engineering is increasingly becoming a formal part of the K-12 curriculum. In addition to the incorporation of engineering in mathematics and science classes, standalone pre-college engineering classes such as those developed by Project Lead The Way (PLTW), the International Technology and Engineering Education Association (ITEEA) and others have also seen tremendous growth that has resulted in more opportunities for students to study engineering and do design projects at the middle and high school ${ }^{4,5}$. These initiatives reach even the youngest students, with curricula and professional development programs like Engineering is Elementary (EiE) working to increase the presence of engineering in the elementary classroom ${ }^{6}$. As a result of these initiatives, students are much more likely to encounter engineering as part of their pre-college studies.

In addition to formal learning within the classroom, numerous opportunities exist for students to learn about engineering in informal learning environments. These include extracurricular programs such as robotics competitions or after school engineering clubs, engineering-focused 
summer camps, and university sponsored pre-college engineering outreach programs designed to engage students and encourage them to pursue further study in engineering ${ }^{7,8}$. Other ways students can be exposed to engineering prior to university include internships at engineering companies and school or community-based maker spaces.

Despite the growth of formal and informal pre-college engineering learning opportunities, relatively little is known about undergraduate engineering students' overall participation in these experiences or how they affect their pursuit of an engineering degree. Research on individual programs such as Project Lead The Way ${ }^{4}$ and FIRST Robotics 9 suggests that students who participate in these programs tend to pursue engineering degrees at higher rates than students who have not participated in pre-college engineering programs, although establishing causal relationships has proven challenging with this work. Participation can positively affect students' transitions from secondary education to undergraduate engineering programs by helping students develop a stronger identity as an engineer and increasing their comfort working as a member of a team to solve open-ended design problems ${ }^{10}$. They also have the potential to negatively affect students' transitions to university engineering programs by creating unrealistic expectations about the content of university engineering courses and the level of mathematic and scientific ability necessary to be successful in most engineering programs ${ }^{10}$.

This project seeks to address these issues through a mixed-methods research approach. Phenomenographic interviews with first-year engineering students resulted in the development of a theoretical framework identifying five distinct ways students experience the transition from pre-college to university engineering programs. These results were used to develop a quantitative research instrument that has been successfully piloted at two institutions, and will be distributed to first-year engineering students at multiple institutions in the spring of 2016 to better understand how pre-college engineering programs and activities influence the experiences of students in first-year engineering programs.

\section{Summary of Work Completed Over the Past Year}

Major work completed over the past year included an analysis of the relationship between precollege engineering participation and students' grades in their First-Year Engineering courses, a large scale survey of First-Year Engineering Students pre-college engineering experiences and differences in participation between different engineering majors, and the development of a quantitative instrument to assess students' experiences of the transition from pre-college to firstyear engineering programs. Brief summaries of each of these findings (several of which have been published in earlier conference proceedings) are presented in the following sections.

\section{Effects of Participation in Pre-College Engineering Activities on First-Year Engineering Achievement}

In 2013, a cohort of 229 first-year engineering students at Purdue University completed a survey on their pre-college experiences, along with consent to access their academic records to explore the relationship between pre-college participation and their university grades. Table 1 shows the relationships between the context of pre-college engineering participation and students' grades in their first two engineering and mathematics classes at Purdue University. T-tests on these data 
showed no significant differences between students who had participated in various types of precollege engineering activities and students who had not.

Table 1: Differences in mean first-year course grades by context of pre-college engineering participation

\section{Course Mean Grades and Sample Sizes}

\begin{tabular}{|c|c|c|c|c|c|c|}
\hline \multicolumn{2}{|l|}{ Context } & $\%$ & ENGR 1 & ENGR 2 & Math 1 & Math 2 \\
\hline \multirow{2}{*}{$\begin{array}{l}\text { Elementary } \\
\text { School }\end{array}$} & $\mathrm{Y}$ & 4.4 & $3.50(10)$ & $3.00(10)$ & $3.00(9)$ & $2.30(10)$ \\
\hline & $\mathrm{N}$ & 95.6 & $3.67(219)$ & $3.11(200)$ & $2.78(199)$ & $2.57(198)$ \\
\hline \multirow[t]{2}{*}{ Middle School } & $\mathrm{Y}$ & 18.3 & $3.62(42)$ & $3.15(40)$ & $2.92(37)$ & $2.50(41)$ \\
\hline & $\mathrm{N}$ & 81.7 & $3.67(187)$ & $3.09(170)$ & $2.76(171)$ & $2.57(167)$ \\
\hline \multirow[t]{2}{*}{ High School } & $\mathrm{Y}$ & 66.8 & $3.65(153)$ & $3.14(142)$ & $2.84(141)$ & 2.57 (139) \\
\hline & $\mathrm{N}$ & 33.2 & $3.67(76)$ & $3.03(68)$ & 2.66 & $2.55(69)$ \\
\hline \multirow[t]{2}{*}{ Extracurricular } & $\mathrm{Y}$ & 32.3 & $3.57(74)$ & $3.04(69)$ & $2.79(69)$ & $2.47(69)$ \\
\hline & $\mathrm{N}$ & 67.7 & $3.70(155)$ & $3.13(141)$ & $2.78(139)$ & $2.60(139)$ \\
\hline \multirow[t]{2}{*}{ Summer Camp } & $\bar{Y}$ & 17.5 & $3.55(40)$ & $3.23(35)$ & $2.59(38)$ & $2.60(36)$ \\
\hline & $\mathrm{N}$ & 82.5 & 3.68 & 3.08 & 2.83 & $2.55(172)$ \\
\hline University & $\mathrm{Y}$ & 14.8 & $3.65(34)$ & $3.07(28)$ & $2.63(29)$ & $2.53(29)$ \\
\hline Program & $\mathrm{N}$ & 85.2 & $3.66(195)$ & $3.11(182)$ & $2.81(179)$ & 2.57 (179) \\
\hline \multirow[t]{2}{*}{ Other } & $\mathrm{Y}$ & 16.6 & $3.58(38)$ & $3.14(35)$ & $2.63(31)$ & $2.74(36)$ \\
\hline & $\mathrm{N}$ & 83.4 & $3.68(191)$ & $3.10(175)$ & 2.81 (177) & $2.52(172)$ \\
\hline
\end{tabular}

Mean (Sample Size); No differences significant

Similarly, Table 2 shows differences in mean first-year engineering and mathematics courses broken down by the number of engineering activities students participated in prior to attending university. Again, the differences between students who had participated in pre-college engineering and those who had not were small, and no differences were significant based on $\mathrm{T}$ tests comparing the means.

Table 2: Differences in mean first-year course grades by amount of pre-college engineering participation Course Mean Grades and Sample Sizes

\begin{tabular}{l|r|l|l|l|l}
\hline \multicolumn{2}{l|}{ Participation } & ENGR 1 & ENGR 2 & Math 1 & Math 2 \\
\hline 1 or more & Y & $3.65(178)$ & $3.10(163)$ & $2.79(160)$ & $2.55(164)$ \\
activities & $\mathrm{N}$ & $3.69(51)$ & $3.11(47)$ & $2.76(48)$ & $2.60(44)$ \\
\hline 2 or more & $\mathrm{Y}$ & $3.60(118)$ & $3.16(108)$ & $2.82(106)$ & $2.57(108)$ \\
activities & $\mathrm{N}$ & $3.72(111)$ & $3.05(102)$ & $2.75(102)$ & $2.55(100)$ \\
\hline 3 or more & $\mathrm{Y}$ & $3.61(70)$ & $3.22(65)$ & $2.70(63)$ & $2.50(66)$ \\
activities & $\mathrm{N}$ & $3.68(159)$ & $3.06(145)$ & $2.82(145)$ & $2.59(142)$ \\
\hline 4 or more & $\mathrm{Y}$ & $3.59(39)$ & $3.25(36)$ & $2.63(34)$ & $2.38(38)$ \\
activities & $\mathrm{N}$ & $3.67(190)$ & $3.07(174)$ & $2.82(174)$ & $2.60(170)$ \\
\hline \multicolumn{5}{c}{ Mean (Sample Size); No differences significant }
\end{tabular}

Although these initial analyses do not demonstrate significant differences between students who have participated in pre-college engineering experiences and those who had not, we are continuing to track these students as they enter into the disciplinary engineering programs and will be exploring the relationship between pre-college engineering participation and students' persistence in earning their chosen engineering degrees. 


\section{Variation in Pre-College Participation between Engineering Majors}

A second study conducted this year for this project involved a brief survey of all First-Year Engineering students at Purdue University that asked for their first choice of engineering major and their exposure to pre-college engineering across nine different contexts. The contexts were elementary school class, middle school engineering class, engineering within a middle school mathematics or science class, high school engineering class, engineering within a high school mathematics or science class, extracurricular activity, university-sponsored pre-college engineering activity, and other. For each of the contexts, students chose one of the following levels of participation: no exposure, minimal exposure, one project or class, two projects or classes, three projects or classes, and four or more projects or classes.

A total of 1576 students completed the survey, and of these respondents 1227 or approximately $78 \%$ indicated at least one context where they had more than minimal exposure to engineering prior to attending university. Comparing the mean levels of participation for each major to the population mean showed wide variation between the majors. Civil, nuclear, and electrical and computer engineering had the highest rates of pre-college engineering participation, while environmental, chemical, and those intending to leave engineering after the first year had the lowest rates of pre-college engineering participation. These data suggest that either pre-college engineering experiences may influence students' choice of major, or that students tend to self select into pre-college engineering activities based on their interests which are in turn related to their choice of engineering major.

\section{Development of Quantitative Instrument}

In the first phase of this project, completed last year, phenomenographic interviews with firstyear engineering students explored how their experiences with engineering prior to university influenced their transitions to first-year engineering. Analysis of these data resulted in the development of a theoretical framework identifying five distinct ways of experiencing the transition from pre-college to first-year engineering shown in Figure 1. 


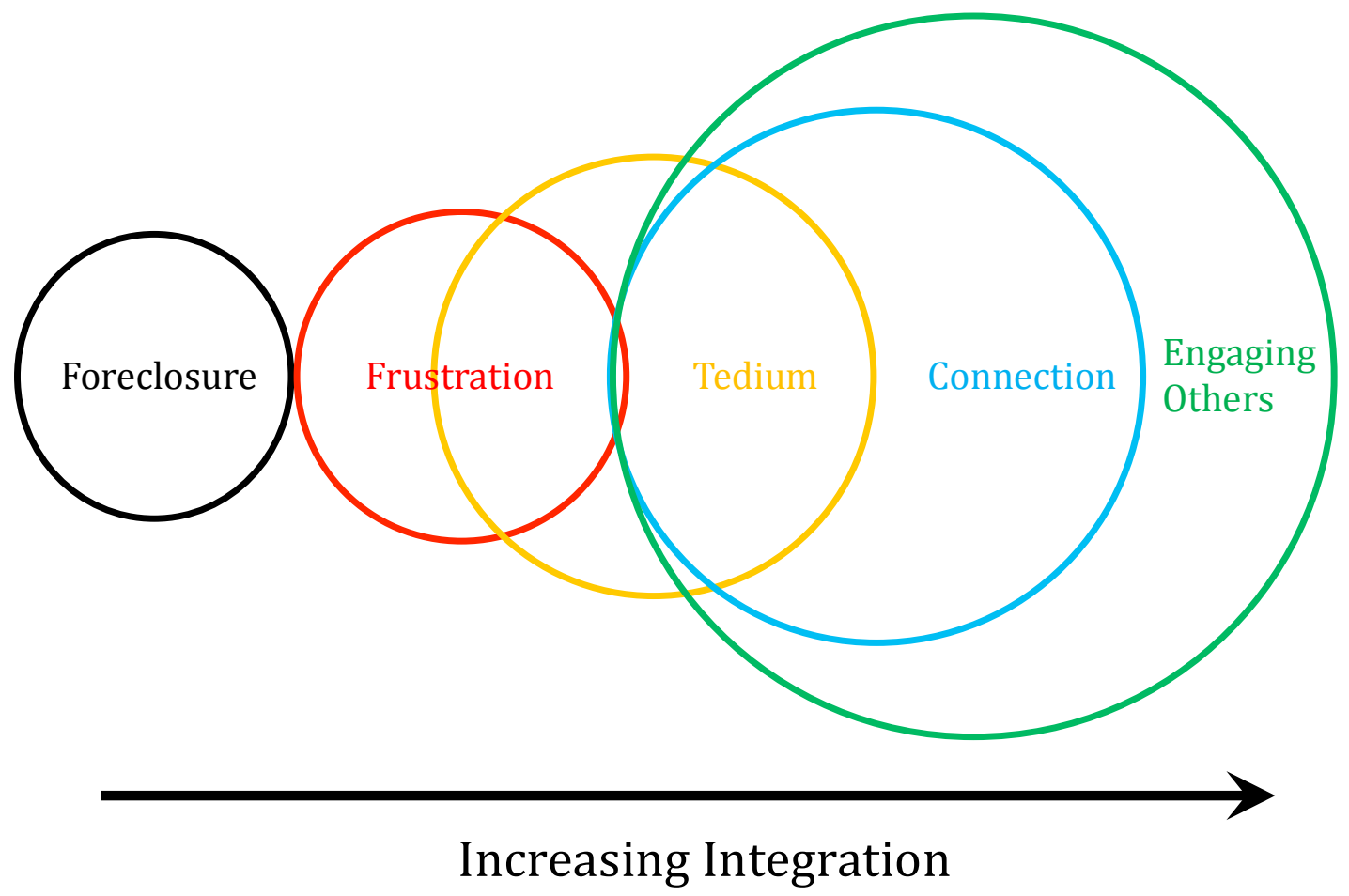

Figure 1: Phenomenographic outcome space of ways of experiencing the transition from precollege to first-year engineering.

Over the past year, these qualitative results were utilized to develop a survey instrument to allow for the collection of quantitative data from a larger sample of students. This involved creating Likert-style survey items based on the qualitative data, using the statements provided by the students whose experiences informed the qualitative results to create items for the instrument. The instrument was validated by expert review, where multiple individuals with knowledge of pre-college and/or first-year engineering programs provided feedback on the initial instrument. A pilot version of the instrument was administered using the Qualtrics online survey tool to students at both Boise State University $(\mathrm{N}=152)$ and Purdue University $(\mathrm{N}=127)$. The survey items and associated mean and standard deviation for each item at each of the two institutions grouped by construct is shown in Table 3 .

Table 3: Initial instrument items, means, and standard deviations.

$\begin{array}{ll}\text { Boise State } & \text { Purdue } \\ \text { Mean SD Mean SD }\end{array}$

\section{Foreclosure}

1. I chose engineering as a major because I didn't know what else $\quad \begin{array}{llll}2.09 & 1.03 & 2.20 & 1.11\end{array}$ to do

2. I feel trapped in engineering $\quad \begin{array}{llll}2.27 & 1.04 & 2.08 & 0.91\end{array}$

3. I'd rather be studying something besides engineering $\quad \begin{array}{llll}2.14 & 1.02 & 2.26 & 1.03\end{array}$

4. I majored in engineering because I was expected to $\quad \begin{array}{llll}2.38 & 1.20 & 2.48 & 1.05\end{array}$

5. I've never considered majoring in anything other than $\begin{array}{lllll}2.65 & 1.30 & 2.70 & 1.28\end{array}$ engineering

6. I am mostly studying engineering because of the influence of $\quad \begin{array}{lllll}2.70 & 1.00 & 2.70 & 1.04\end{array}$ other people 


\section{Frustration}

1. I am struggling academically in my university engineering
program

2. If I didn't participate in pre-college engineering programs, I $\quad \begin{array}{llll}2.87 & 1.16 & 2.28 & 0.98\end{array}$ probably wouldn't be in engineering right now

$\begin{array}{llllll}3 . & \text { University engineering courses are less welcoming than my pre- } & 2.78 & 0.89 & 2.71 & 0.93\end{array}$ college engineering experiences

4. The pre-college engineering activities I participated in were more $\quad \begin{array}{llll}2.80 & 1.02 & 2.87 & 1.18\end{array}$ like real engineering than what I am doing now in university engineering

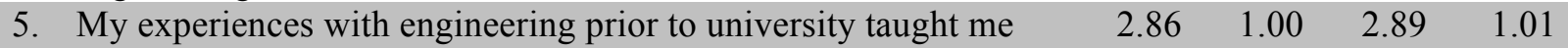
what to expect in a university engineering curriculum

6. I am frustrated by the lack of hands-on projects and activities in $\quad \begin{array}{llll}2.80 & 0.95 & 3.11 & 0.99\end{array}$ my engineering courses

7. I felt a stronger sense of connection to my teammates or $\quad \begin{array}{lllll}3.13 & 1.05 & 2.94 & 1.06\end{array}$ classmates in my pre-college engineering experiences than in my college engineering classes

8. My pre-college engineering projects were more exciting than the $\begin{array}{llll}2.93 & 1.05 & 3.23 & 1.16\end{array}$ projects I have done so far at the university

9. I have sought out other opportunities to do engineering at the $\quad \begin{array}{lllll}3.11 & 0.99 & 3.09 & 1.01\end{array}$ university or in the community outside of my engineering courses

10. Participation in pre-college engineering programs has helped me $\quad \begin{array}{llll}3.13 & 0.97 & 3.10 & 0.93\end{array}$ to overcome frustration that I have experienced in my university engineering program

11. I think that my university engineering classes are weed-out $\quad \begin{array}{lllll}3.00 & 1.04 & 3.26 & 1.14\end{array}$ classes

12. Based on my pre-college engineering experiences, I thought $\quad \begin{array}{lllll}3.02 & 0.99 & 3.41 & 1.02\end{array}$ engineering in college would be more hands-on

13. The engineering I am doing at the university is more like the $\quad \begin{array}{lllll}3.30 & 0.87 & 3.35 & 0.90\end{array}$ work of a practicing engineer that what I did before college

14. I feel a strong sense of connection to my teammates or $\quad \begin{array}{llll}3.28 & 0.92 & 3.39 & 0.96\end{array}$ classmates in my university engineering courses

15. I am motivated to be successful in engineering because of my $\quad \begin{array}{lllll}3.43 & 0.91 & 3.48 & 0.96\end{array}$ experiences with engineering prior to university

16. My experiences with engineering prior to university prepared me $\quad \begin{array}{llll}3.43 & 0.96 & 3.53 & 0.93\end{array}$ to understand the role and importance of science to engineering

\begin{tabular}{lllll} 
17. I would rather be doing things with my hands than learning & 3.66 & 1.02 & 3.51 & 1.11 \\
theory & 3.74 & 0.95 & 3.43 & 0.98 \\
18. University engineering is fun & 3.60 & 0.95 & 3.63 & 0.93 \\
19. $\begin{array}{l}\text { My experiences with engineering prior to university prepared me } \\
\text { to understand the role and importance of mathematics to } \\
\text { engineering }\end{array}$ & 3.65 & 0.96 & 3.61 & 0.98 \\
\hline 20. & & & & \\
21. I feel like I belong in engineering & 3.95 & 0.87 & 3.97 & 0.83 \\
22. I will graduate with a degree in engineering & 4.17 & 0.93 & 4.37 & 0.76 \\
& & & & \\
$\quad$ Tedium & & & & \\
1. I don't have to work as hard in university engineering classes as I & 2.42 & 0.96 & 2.46 & 1.10
\end{tabular}


2. My university engineering courses are less academically

$\begin{array}{llll}2.62 & 0.97 & 2.34 & 0.97\end{array}$ challenging than my pre-college engineering classes and activities

3. My pre-college engineering programs and classes had higher $\quad \begin{array}{llll}2.73 & 0.92 & 2.54 & 1.06\end{array}$ expectations than my university engineering classes

4. I am less motivated to do my university engineering projects than $\quad \begin{array}{lllll}2.56 & 0.96 & 2.73 & 1.07\end{array}$

I was when I was working on my pre-college engineering projects

5. I am bored relearning things that I already learned in my pre- $\quad \begin{array}{lllll}2.73 & 1.08 & 2.82 & 1.12\end{array}$ college engineering experiences

$\begin{array}{llllll}\text { 6. I learned most of what is being taught in my university } & 2.81 & 1.07 & 2.79 & 1.06\end{array}$ engineering classes in my pre-college engineering classes and programs

7. I could probably have skipped one or more of my introductory or $\quad \begin{array}{llll}2.76 & 1.14 & 3.16 & 1.25\end{array}$ freshman-level engineering courses because of my pre-college engineering experiences

8. Most of my team's designs are based mostly on my ideas $\quad \begin{array}{lllll}3.07 & 0.80 & 2.94 & 0.81\end{array}$

9. I tend to do most of the work on my team's engineering design $\quad \begin{array}{lllll}3.16 & 0.91 & 3.02 & 1.02\end{array}$ projects

10. I had more control over my pre-college engineering projects than $\begin{array}{llll}2.95 & 0.94 & 3.25 & 1.10\end{array}$ I do over my university engineering projects

11. My transition from pre-college to university engineering has $\quad \begin{array}{lllll}3.16 & 0.99 & 3.34 & 0.99\end{array}$ been easy

12. I am more comfortable than my peers solving open-ended $\quad \begin{array}{lllll}3.35 & 0.86 & 3.38 & 0.81\end{array}$ problems that can have more than one right answer

\section{Connection}

1. University engineering looks a lot like pre-college engineering $\quad \begin{array}{lllll}2.80 & 0.89 & 2.57 & 0.99\end{array}$

2. Engineering design in my university courses is similar to the $\quad \begin{array}{llllll}2.91 & 0.90 & 2.87 & 0.97\end{array}$ engineering design that I did in my pre-college engineering classes and activities

3. My pre-college engineering classes and activities prepared me $\quad \begin{array}{lllll}3.11 & 1.00 & 3.20 & 1.04\end{array}$ for the challenges of studying engineering at the university
4. I am better prepared for university engineering because I participated in engineering program and activities prior to university

5. I am confident in my ability to do engineering design in my $\quad \begin{array}{lllll}3.18 & 0.99 & 3.28 & 1.08\end{array}$ university engineering courses because I did engineering design prior to university

6. My pre-college engineering experiences helped me learn how to $\quad \begin{array}{llll}3.30 & 0.91 & 3.22 & 1.01\end{array}$ overcome the challenges I have faced in university engineering

7. My pre-college engineering experiences gave me a bigger picture $\quad \begin{array}{lllll}3.26 & 1.06 & 3.27 & 1.03\end{array}$ of what engineers do

8. Learning similar content in my pre-college engineering classes $\quad \begin{array}{lllll}3.32 & 0.88 & 3.29 & 0.98\end{array}$ and activities has helped me to be more successful in my university engineering courses

9. My pre-college engineering experiences gave me a bigger picture $\quad \begin{array}{llll}3.38 & 1.02 & 3.27 & 0.99\end{array}$ of what engineering is

10. I can solve open-ended problems with more than one right answer because I solved these kinds of problems in my precollege engineering activities 


\begin{tabular}{|c|c|c|c|c|c|}
\hline 11. & $\begin{array}{l}\text { Working on an engineering team before coming to the university } \\
\text { has helped me to work on a team as part of my university } \\
\text { engineering classes }\end{array}$ & 3.31 & 0.91 & 3.46 & 0.98 \\
\hline 12. & $\begin{array}{l}\text { My transition from pre-college to university engineering has } \\
\text { been fairly smooth }\end{array}$ & 3.29 & 0.97 & 3.65 & 0.84 \\
\hline 13. & $\begin{array}{l}\text { Taking risks is an important part of the engineering design } \\
\text { process }\end{array}$ & 3.72 & 0.89 & 3.88 & 0.78 \\
\hline \multirow[t]{2}{*}{14.} & Failure is a normal part of the engineering design process & 4.11 & 0.77 & 4.06 & 0.82 \\
\hline & \multicolumn{5}{|l|}{ Engaging Others } \\
\hline 1. & My teammates tend to look towards me for leadership & 3.39 & 0.81 & 3.33 & 0.87 \\
\hline 2. & $\begin{array}{l}\text { My engineering team tends to work better than others that I see } \\
\text { in this class }\end{array}$ & 3.30 & 0.85 & 3.60 & 1.02 \\
\hline 3. & $\begin{array}{l}\text { My teammates look to me for advice and guidance when we are } \\
\text { doing engineering design }\end{array}$ & 3.52 & 0.81 & 3.52 & 0.76 \\
\hline 4. & $\begin{array}{l}\text { I am good at encouraging my teammates to contribute their ideas } \\
\text { to the engineering design process }\end{array}$ & 3.66 & 0.74 & 3.80 & 0.79 \\
\hline 5. & $\begin{array}{l}\text { Compromise is an important part of the engineering design } \\
\text { process }\end{array}$ & 3.71 & 0.81 & 3.88 & 0.86 \\
\hline 6. & $\begin{array}{l}\text { I am patient with other peoples' ideas, even if they're different } \\
\text { than how I would approach a problem }\end{array}$ & 3.83 & 0.82 & 3.77 & 0.84 \\
\hline 7. & $\begin{array}{l}\text { I incorporate ideas and feedback from my teammates when we } \\
\text { are working on an engineering design problem }\end{array}$ & 3.82 & 0.87 & 3.86 & 0.72 \\
\hline 8. & I like helping other people on my team to be successful & 4.06 & 0.75 & 3.94 & 0.69 \\
\hline 9. & I am comfortable working with people who are different than me & 4.04 & 0.89 & 4.01 & 0.83 \\
\hline 10. & $\begin{array}{l}\text { It's useful to have multiple perspectives/lots of peoples' ideas } \\
\text { when doing engineering design }\end{array}$ & 4.12 & 0.93 & 4.18 & 0.71 \\
\hline 11. & $\begin{array}{l}\text { It's important to listen to your teammates when doing } \\
\text { engineering design }\end{array}$ & 4.30 & 0.84 & 4.23 & 0.72 \\
\hline
\end{tabular}

\section{Discussion}

The results shown in Table 3 suggest most of the items in the instrument are functioning fairly well. Most items have a standard deviation of approximately one on a five point scale, indicating that for most items there is sufficient variability to establish that respondents are experiencing variation across most aspects of their transitions from pre-college to university engineering. Examining these data also shows that most students do not experience the transition to university engineering as Foreclosure, with lower means across all of the items in this construct. This suggests that most of the respondents do not feel trapped in engineering or pressure to be studying engineering from external forces. Likewise, the overall higher means for Engaging Others suggest that most of the respondents recognize the value of others' contributions to the engineering design process and value working as part of a team.

When examining these results, it is interesting to note that despite significant differences both institutionally and in the first-year engineering curriculum between Purdue University and Boise State University, the means and standard deviations for most of the items are fairly similar. Purdue University is highly ranked nationally across its undergraduate engineering degree offerings, and as a result has a highly competitive admissions process and attracts top students from across the United States and around the world. Boise State University is a well-regarded 
regional institution, but is nationally ranked significantly lower that Purdue University with a much less competitive admissions process. The first-year engineering curricula also vary considerable between the institutions. Purdue University has a two-semester first-year engineering sequence focused primarily on design and programming with a strong focus on developing students' ability to work on a team, while Boise State University has single first-year engineering course with a strong focus on developing students' mathematics capabilities. Even though the institutional and student characteristics and the curricula are quite different between the two institutions, the similarities in the responses to the instrument suggest that students' experience their transitions from pre-college to university engineering in similar ways which in turn suggests that the theoretical framework developed earlier in the study can help understand students' experiences across a variety of institutions.

\section{Future Work}

As of writing, data collected from the pilot administration of the survey are being analyzed to assess the reliability of the instrument and make change prior to distributing the survey to a larger sample of students across multiple institutions in the spring of 2016. This will include assessing the overall reliability of the instrument, the reliability of the five subscales representing the five ways of experiencing the transition from pre-college to university engineering, and identifying and removing items that reduce the reliability of this instrument. The final instrument will then be distributed to new populations of students at Boise State University and Purdue University, along with distribution to four other institutions that will contribute additional demographic, institutional, and curricular diversity. The resulting data will be used to understand students' transitions to university engineering programs, identify and explore variation in students' pre-college engineering experiences and how these experiences influence their transition to first-year engineering, and provide valuable information to both the participating institutions and the larger first-year and pre-college engineering communities to facilitate better alignment between their programs and curricula.

\section{Publications to Date}

- Salzman, N., \& Ohland, M. W. (2015). Effects of Pre-College Engineering Participation on First-Year Engineering Outcomes. Presented at the 2015 IEEE Frontiers in Education Conference, El Paso.

- Salzman, N., \& Ohland, M. W. (2015). Differences in Pre-College Engineering Participation Between Engineering Majors. Presented at the 7th First Year Engineering Experience (FYEE) Conference. Roanoke, VA.

- Salzman, N., Ohland, M. W., \& Cardella, M. E. (2015). Measuring the Effects of Precollege Engineering Education, Year 2. Presented at the American Society for Engineering Education Annual Conference, Seattle, WA.

- Salzman, N. (2014). A Phenomenographic Study Of Students' Experiences With Transition From Pre-College Engineering Programs To First-Year Engineering (Doctoral dissertation). Purdue University, West Lafayette, IN.

- Salzman, N., Ohland, M. W., \& Cardella, M. E. (2014). Measuring the Effects of Precollege Engineering Education. Presented at the American Society for Engineering Education Annual Conference, Indianapolis, IN. 
- Salzman, N., Ohland, M. W., \& Cardella, M. E. (2014). Work In Progress-A Qualitative Study of the Effects of Participation in Pre-College Engineering Programs on First-Year Engineering Students. Presented at the 2014 IEEE Frontiers in Education Conference, Madrid.

- Salzman, N., Ricco, G. D., \& Ohland, M. W. (2014). Pre-College Engineering Participation Among First-Year Engineering Students. Presented at the American Society for Engineering Education Annual Conference, Indianapolis, IN.

- Salzman, N., \& Ohland, M. W. (2013). Precollege Engineering Participation among First-Year Engineering Students. Presented at the 5th First Year Engineering Experience (FYEE) Conference. Pittsburg, PA.

\section{Acknowledgements}

The authors would also like to acknowledge the support of the National Science Foundation (EEC Grant \# 1550961). Any opinions, findings, conclusions, or recommendations do not necessarily reflect the views of the National Science Foundation. The authors would also like to thank Dr. Cathleen Barczys Simons and Dr. Stephen Hoffman for assistance with data collection and analysis for this project.

\section{References}

1. Carr, R. L., Bennett, L. D. \& Strobel, J. Engineering in the K 12 STEM Standards of the 50 US States: An Analysis of Presence and Extent. Journal of Engineering Education 101, 539564 (2012).

2. Moore, T. J., Tank, K. M., Glancy, A. W. \& Kersten, J. A. NGSS and the landscape of engineering in K-12 state science standards. J Res Sci Teach 52, 296-318 (2015).

3. National Research Council. Next Generation Science Standards: For States, By States. (The National Academies Press, 2014).

4. Tai, R. H. An Examination of the Research Literature on Project Lead The Way. (Project Lead The Way, 2012).

5. Strimel, G. Engineering by Design ${ }^{\mathrm{TM}}$ : Preparing Students For the 21 st Century. in $434-443$ (2012).

6. Cunningham, C. Elementary Teacher Professional Development in Engineering: Lessons Learned from Engineering is Elementary. in 2008 ASEE Annual Conference and Exposition, June 22, 2008 - June 24, 2008 (2008).

7. Brophy, S., Klein, S., Portsmore, M. \& Rogers, C. Advancing Engineering Education in P-12 Classrooms. Journal of Engineering Education 97, 369-387 (2008).

8. National Academy of Engineering \& National Research Council. Engineering in K-12 education: Understanding the Status and Improving the Prospects. (The National Academies Press, 2009).

9. Melchior, A., Burack, C., Gutbezahl, J., Hoover, M. \& Marcus, J. FIRST Longitudinal Study: Summary of Preliminary Findings - Year 2. (The Center for Youth and Communities, Brandeis University, 2015). 
10. Salzman, N., Ricco, G. D. \& Ohland, M. W. Pre-College Engineering Participation Among First-Year Engineering Students. in (2014). 